\title{
Contents volume 15 (1997)
}

Continuing education and training programmes for library and information personnel in South Africa's educational institutions

A.M. Kaniki

Training information service specialists in the less-favoured regions of the European Union (TRAIN-ISS): the diploma/MSc programme at the University of Sheffield

I. Owens, F. Wood, T. Wilson and A.M. Ramalho Correia

From Michelangelo to $2001 \mathrm{AD}$ : information crafting - a new art M.E. Burke

A wider horizon to information handling: teaching abstracting to students of translation T. Koltay

Telework 96: an international collaborative learning package for information entrepreneurs

E. Davenport and I. Wormell

Online Information 96, 3-5 December 1996, Olympia 2, London, UK

(Short Communication)

F. Guy

Book reviews

News

Editorial

A. Large

Undergraduate degrees in information and library studies: a retrospect and revaluation K.J. McGarry

Undergraduate library and information science education at Aberystwyth

D. Stoker

Undergraduate library and information studies programs in North America A. Large

A new approach to information education

G.T. Sherron

Undergraduate information programmes in Australia: a brief survey G.S. Wagner 


\section{Book reviews}

Editorial

A. Large

Information technology and library education in Pakistan: recent developments in the curriculum

K. Mahmood

The International Graduate Summer School in librarianship at Aberystwyth - a look back over 25 years

L.A. Tedd

The Chinese academic library: its situation and problems (Short Communication) $\mathrm{X}$. Yang and $\mathrm{Rx}$ Cheng

Preparing LIS graduates for the 'emerging market': an Australian educator down under in the UK (Short Communication)

S. Ferguson

Teaching information sources and business information sources and services at the Department of Library and Information Sciences at György Bessenyei Teachers' Training College (News from the Schools)

Á. Szerafin-Szabolcsi and A. Tanyi-Kocsis 235

$\begin{array}{ll}\text { Book reviews } & 241\end{array}$

$\begin{array}{lr}\text { News } & 257\end{array}$

$\begin{array}{ll}\text { Erratum } & 279\end{array}$

Editorial

D. Zeitlyn and J. Bex 281

Conversation and discourse analysis in library and information services

M.A. Forrester, C. Ramsden and D. Reason

Libraries, hospitals and schools: a new research frontier

L. Banwell and C. Edwards

Libraries as information environments

D. Rosenberg

Exploring the use of interactive information systems in academic research: borrowing from the ethnographic tradition

D. Squires

Joking, being aggressive and shutting people up: the use of focus groups in LIS research

A. Goulding

The information needs interview: a long way from library-use statistics

D. Nicholas 
Cultural and technical networks: a qualitative approach D. Zeitlyn, J. Bex and M. David

News

Erratum

Author index volume 15

Contents volume 15 